\title{
Winter distribution of macroplankton and micronekton in Masfjorden, western Norway
}

\author{
Stein Kaartvedt, Dag L. Aksnes, Agnes Aadnesen \\ Department of Marine Biology, University of Bergen, N-5065 Blomsterdalen, Norway
}

\begin{abstract}
Masfjorden was investigated as a potential site for sea ranching of cod. The macroplankton and micronekton were studied in order to reveal the distributional patterns of species and biomass during winter. The biomass was dominated by the mesopelagic fishes Benthosema glaciale and Maurolicus muellen, the pelagic shrimps Pasiphaea multidentata and Sergestes arcticus, and the euphausiid Meganyctiphanes norvegica. All species performed diel vertical migrations. B. glaciale was almost exclusively found in the deepest locations $(>400 \mathrm{~m}) . M$. muelleri was found throughout the fjord, but large individuals were most common at one of the deep stations. The shrimps were mainly confined to the deeper parts of the fjord, where the 2 species were prominent in separate basins. The largest individuals were found at the deepest locations. The distribution of $M$. norvegica seemed to be unrelated to the topography. There was a marked maximum of euphausiids at the head of the fjord; these were probably advected into the fjord system. The total standing stock of macroplankton and micronekton was estimated to be 19.5 tome ash-free dry weight. We conclude that the amount of macroplankton and micronekton present in Masfjorden does not provide a food resource on which several hundred thousand codlings could rely during winter
\end{abstract}

\section{INTRODUCTION}

Masfjorden (Fig. 1) has been selected to study the potential of enhancing natural populations of coastal cod Gadus morhua L. by means of releasing artificially reared young cod. In Scottish sea lochs, it has been shown that the production of juvenile cod may be limited by the winter food supply (Hawkins et al. 1985). Therefore, as a measure of the carrying capacity of the fjord, the standing stock of food organisms in winter may be of special interest. The cod stock in Masfjorden at present feeds mainly on benthic prey and gobiid fishes along the shallow sublittoral parts of the fjord. Gobiids are the most important prey for cod less than $20 \mathrm{~cm}$ length (Salvanes 1986). Cod is, however, known to feed on a variety of prey (e.g. Rae 1968, Daan 1973, Klemetsen 1982). By significantly increasing the cod stock in Masfjorden, it is conceivable that new areas would be inhabited and that predation pressure on the macroplankton and micronekton would increase.

Macroplankton and micronekton are important prey for cod in fjords of northern Norway (Falk-Petersen \& Hopkins 1981, dos Santos \& Falk-Petersen in press), and these groups may also play an important role in the transfer of organic material in pelagic communities of fjords in western Norway (Gjøsæter 1973, 1981, Matthews \& Bakke 1977). Both the biomass and ecology of such organisms in fjords, however, are generally poorly known.

This paper has 2 objectives. First, to contribute to the general knowledge of the macroplankton and micronekton in fjords, and second, to relate our results to the cod release project. Spatial patterns of the community composition in Masfjorden during winter will be addressed, and the results are interpreted with regard to the topography of the fjord, hydrography, advective processes, and biological interactions. To evaluate the potential of macroplankton and micronekton as food for cod, estimates of the total standing stock of macroplankton and micronekton in Masfjorden are compared to food requirements of juvenile cod.

\section{THE STUDY AREA}

Masfjorden is a $20 \mathrm{~km}$ long fjord situated north of Bergen, western Norway (Fig. 1). The fjord borders on Fensfjorden, through which it is connected to outer 


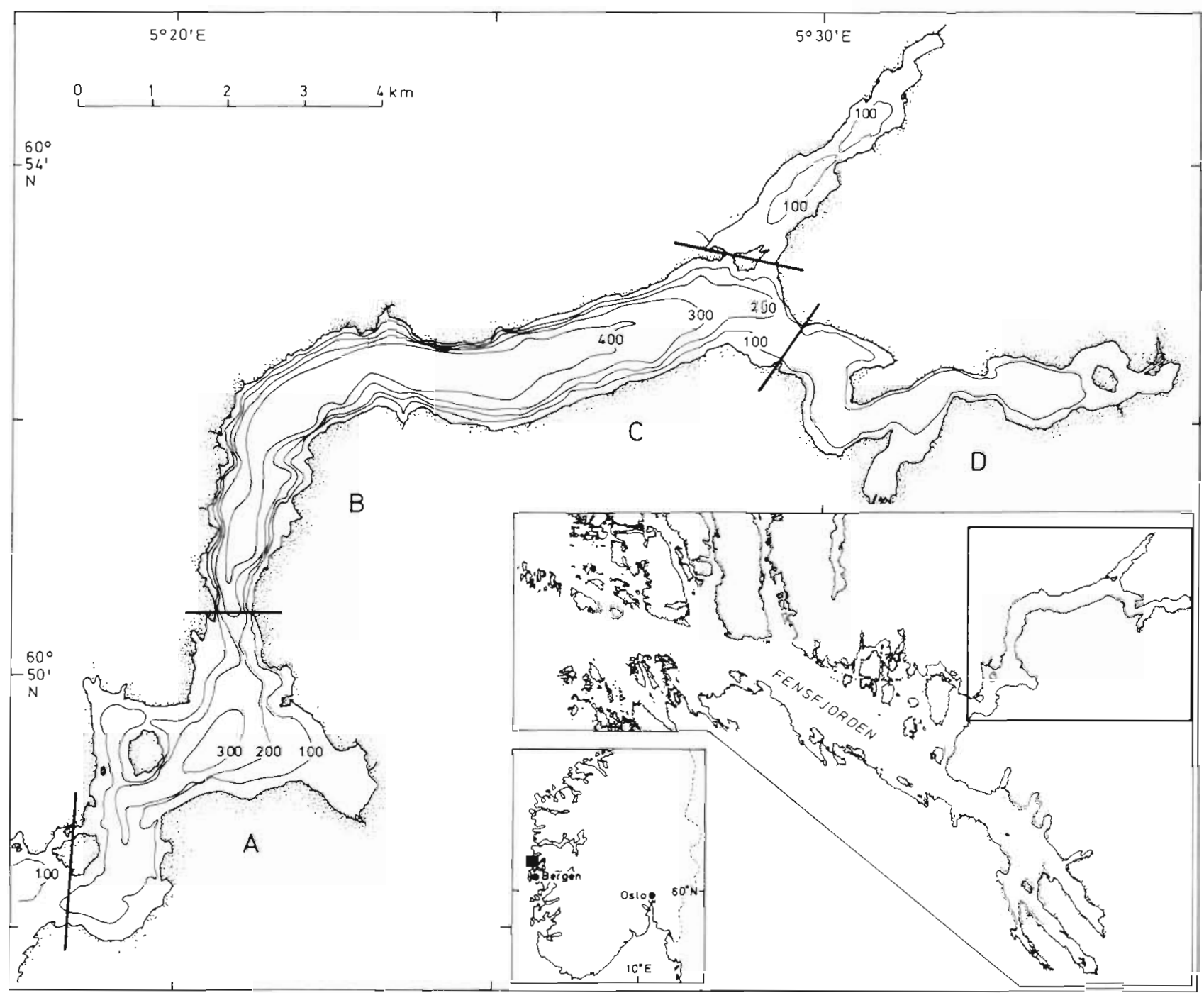

Fig. 1. Masfjorden with bottom contours $(m)$. Borders of Stns $A, B+C$, and D are given. Sampling was performed along the deep mid-parts of the basins

coastal waters. At times, intrusions of coastal waters may play an important ecological role. A large impact of advective processes on mesoplankton has been demonstrated by Aksnes et al. (unpubl.), who conclude that the standing stock of mesoplankton in the fjord is to a large extent a result of exchange of biomass across the sill.

Sill depth in Masfjorden is $75 \mathrm{~m}$, and maximum depth is $494 \mathrm{~m}$. The topography of the fjord is outlined in Fig. 1. At the head of the inner southern branch of the fjord, there is a hydroelectric power plant, supplying the fjord with freshwater at a maximum rate of $50 \mathrm{~m}^{3} \mathrm{~s}^{-1}$ This runoff causes a short residence time of the surface waters, resulting in ice-free conditions along the main axis of the fjord during winter (Sætre 1974). During our survey, the inner northern branch was covered with ice, preventing sampling in this region.

\section{MATERIAL AND METHODS}

The main sampling was carried out on 10 to 14 January 1986 from the RV 'Håkon Mosby'. Supplementary samples were collected in December 1986 and January 1987. In January 1986 samples were collected by 2 Isaac-Kidd Midwater Trawls (IKMT), 1 large IKMT (LIKMT) with a mouth aperture of $10 \mathrm{~m}^{2}$ (specifications are given by Anonymous 1981), and 1 smaller IKMT (SIKMT) with mouth aperture of $2 / 3 \mathrm{~m}^{2}$ (a $3 \mathrm{ft}$ IKMT, Aron 1962). The net in the L-IKMT had decreasing mesh size backwards, from $25 \mathrm{~mm}$ in the front to $1.15 \mathrm{~mm}$ at the rear part. The net of the S-IKMT was $2 \mathrm{~mm}$ throughout. On each of Stns A to D (Fig. 1), oblique tows covering a depth range of approximately $100 \mathrm{~m}$ were conducted. The actual depth interval sampled was determined using a Benthos Time-Depth recorder. Due to the short 
day at latitude $60^{\circ} 50^{\prime} \mathrm{N}$ during winter, time for sampling during daylight was limited. Thus, Stns A and D were sampled during darkness only. Details are given in Table 1.

The IKMT's were towed at a speed of 3 knot. Since they had no closing device, the speed of the ship was kept lower during shooting and hauling to reduce fishing outside the desired depth interval. Nevertheless, contamination from upper layers may have been noteworthy, especially for the deepest tows. The catches were therefore corrected by reference to the catches in the shallower tows, for the time spent fishing in the upper layer of water during shooting and hauling (Table 1). Any differences in sampling efficiency during shooting and hauling have not been accounted for.

In December 1986 and January 1987, only the SIKMT was used. Each station was sampled by 2 oblique tows per day and per night - one from near the bottom to the surface, and one from approximately $100 \mathrm{~m}$ to the surface (Table 2). The net was towed at 3 knot throughout the haul.

The January 1986 samples were split into 2 parts by a modified Folsom splitter (Motoda 1959). One part was preserved in $4 \%$ buffered formaldehyde for identifica- tion, counting, and measuring size. The other part was frozen for biomass determinations after having sorted the catch into the categories 'fish', 'shrimps', 'euphausiids', and 'other taxa'. Prior to biomass determination, shrimps and fishes were counted in the frozen fraction. In December 1986 and January 1987, the entire sample was frozen (split into categories as above) after counting the shrimps and fishes on board.

Size of fish is given as standard length, i.e. excluding the caudal fin. Carapace length in shrimps was measured from the hind orbit of the eye to the mid posterior dorsal margin. Dry weight was determined by drying the samples at $60^{\circ} \mathrm{C}$ to constant weight. The samples were then burnt at $500^{\circ} \mathrm{C}$ for determination of ash content.

Differences in abundance between stations were tested by single classification ANOVA on log-transformed data from the night tows with the L-IKMT (Sokal \& Rohlf 1981). Tests were done both per unit surface area and on densities (per $\mathrm{m}^{3}$ ). Given levels of significance were satisfied in both tests. In the analysis, tows from different depths at a station were treated as 'replicates'. This introduces an extra 'within station' variance in species confined to restricted depth inter-

Table 1. Sampling data from the survey in Masfjorden, January 1986. Distances towed in and out of the sample intervals are given. L-IKMT and S-IKMT: large and small Isaac-Kidd Midwater Trawl nets, respectively

\begin{tabular}{|c|c|c|c|c|c|c|c|c|c|c|}
\hline \multirow[t]{3}{*}{ Stn } & \multicolumn{5}{|c|}{ L-IKMT } & \multicolumn{5}{|c|}{ S-IKMT } \\
\hline & \multirow{2}{*}{$\begin{array}{l}\text { Time of } \\
\text { tow }(h)\end{array}$} & \multirow[t]{2}{*}{ Date } & \multirow{2}{*}{$\begin{array}{l}\text { Tow } \\
\text { depth } \\
(\mathrm{m})\end{array}$} & \multicolumn{2}{|c|}{ Distance (m) } & \multirow{2}{*}{$\begin{array}{l}\text { Time of } \\
\text { tow (h) }\end{array}$} & \multirow[t]{2}{*}{ Date } & \multirow{2}{*}{$\begin{array}{c}\text { Tow } \\
\text { depth } \\
(\mathrm{m})\end{array}$} & \multicolumn{2}{|c|}{ Distance $(\mathrm{m})$} \\
\hline & & & & In & Out & & & & In & Out \\
\hline \multirow[t]{4}{*}{ A } & $22: 07-22: 39$ & $10 \mathrm{Jan}$ & $80-0$ & 2718 & 0 & & & & & \\
\hline & $21: 03-21: 45$ & & $220-80$ & 2698 & 1044 & & & & & \\
\hline & $19: 10-19: 35$ & $13 \mathrm{Jan}$ & $100-0$ & 1743 & 0 & & & & & \\
\hline & $19: 54-20: 30$ & & $120-0$ & 3309 & 0 & & & & & \\
\hline \multirow[t]{8}{*}{ B } & $23: 09-23: 46$ & $10 \mathrm{Jan}$ & $100-0$ & 3269 & 0 & $01: 50-02: 20$ & $13 \mathrm{Jan}$ & $150-0$ & 2898 & 0 \\
\hline & $00: 15-00: 50$ & 11 Jan & $310-100$ & 2559 & 898 & $03: 55-04: 39$ & & $200-140$ & 2256 & 1932 \\
\hline & $02: 08-02: 40$ & & $380-120$ & 2427 & 845 & $04: 52-05: 54$ & & $360-190$ & 3666 & 2372 \\
\hline & $01: 15-01: 45$ & & $420-180$ & 2254 & 1104 & $08: 12-09: 02$ & & $370-250$ & 2360 & 2585 \\
\hline & $10: 05-10: 47$ & & $130-0$ & 3701 & 0 & $10: 06-10: 37$ & $14 \operatorname{Jan}$ & $100-0$ & 2600 & 0 \\
\hline & $11: 04-11: 54$ & & $250-80$ & 3316 & 997 & $10: 55-11: 30$ & & $180-90$ & 2316 & 1091 \\
\hline & $12: 12-12: 58$ & & $430-170$ & 2986 & 1177 & $11: 55-12: 37$ & & $280-200$ & 1934 & 2052 \\
\hline & $13: 17-14: 15$ & & $400-190$ & 3071 & 1589 & $12: 50-13: 49$ & & $400-300$ & 2474 & 3410 \\
\hline \multirow[t]{8}{*}{ C } & $18: 25-19: 03$ & $11 \mathrm{Jan}$ & $95-0$ & 3259 & 0 & $20: 40-21: 09$ & $12 \mathrm{Jan}$ & $100-0$ & 2737 & 0 \\
\hline & $19: 30-20: 20$ & & $230-80$ & 3648 & 765 & $21: 26-22: 08$ & & $210-140$ & 2369 & 1839 \\
\hline & $20: 42-21: 33$ & & $380-180$ & 2725 & 1190 & $22: 26-23: 20$ & & $320-220$ & 3080 & 2262 \\
\hline & $21: 53-23: 01$ & & $370-220$ & 3509 & 2021 & $23: 38-00: 32$ & & $380-260$ & 2995 & 2403 \\
\hline & $10: 00-10: 35$ & & $100-0$ & 2990 & 0 & $10: 03-10: 32$ & $13 \mathrm{Jan}$ & $110-0$ & 2266 & 0 \\
\hline & $14: 15-14: 53$ & & $165-70$ & 2283 & 888 & $10: 50-11: 31$ & & $190-100$ & 2874 & 1111 \\
\hline & $10: 52-11: 40$ & & $280-85$ & 3320 & 884 & $12: 53-13: 30$ & & $320-240$ & 2178 & 1655 \\
\hline & $15: 10-16: 05$ & & $320-150$ & 3120 & 1323 & $11: 49-12: 42$ & & $350-250$ & 2513 & 2848 \\
\hline \multirow[t]{2}{*}{$\mathrm{D}$} & $07: 19-07: 55$ & 12 Jan & $140-0$ & 3117 & 0 & $19: 19-19: 55$ & $12 \mathrm{Jan}$ & $150-0$ & 3440 & 0 \\
\hline & $18: 15-18: 55$ & & $150-0$ & 3602 & 0 & & & & & \\
\hline
\end{tabular}


Table 2. Sampling data from the surveys in Masfjorden, December 1986 and January 1987 'Missing values

\begin{tabular}{|c|c|c|c|c|c|c|}
\hline \multirow[t]{2}{*}{ Stn } & \multicolumn{3}{|c|}{ December 1986} & \multicolumn{3}{|c|}{ January 1987} \\
\hline & Time of tow $(\mathrm{h})$ & Date & Tow depth & Time of tow $(h)$ & Date & Tow depth \\
\hline \multirow[t]{2}{*}{ A } & $\begin{array}{l}22: 23-22: 44 \\
23: 10-2336\end{array}$ & 1. Dec & $\begin{array}{l}100-0 \\
265-0\end{array}$ & $\begin{array}{l}19: 35-19: 54 \\
18: 15-19: 17\end{array}$ & $12 \mathrm{Jan}$ & $\begin{array}{l}100-0 \\
230-0\end{array}$ \\
\hline & $\begin{array}{l}13: 55-14: 10 \\
14: 17-14: 40\end{array}$ & $\begin{array}{l}5 \mathrm{Dec} \\
3 \mathrm{Dec}\end{array}$ & $\begin{array}{l}105-0 \\
260-0\end{array}$ & $\begin{array}{l}10: 00-10: 25 \\
10: 36-11: 05\end{array}$ & $15 \mathrm{Jan}$ & $\begin{array}{r}75-0 \\
200-0\end{array}$ \\
\hline \multirow[t]{2}{*}{ B } & $\begin{array}{l}03: 46-04: 10 \\
04: 40-05: 20\end{array}$ & $2 \mathrm{Dec}$ & $\begin{array}{l}130-0 \\
365-0\end{array}$ & $\begin{array}{l}07: 53-08: 15 \\
06: 22-07: 04\end{array}$ & $13 \mathrm{Jan}$ & $\begin{array}{r}95-0 \\
300-0\end{array}$ \\
\hline & $\begin{array}{l}11: 55-12: 16 \\
12: 35-13: 15\end{array}$ & $3 \mathrm{Dec}$ & $\begin{array}{l}160-0 \\
420-0\end{array}$ & $\begin{array}{l}10: 20-10: 35 \\
10: 50-11: 20\end{array}$ & & $\begin{array}{r}90-0 \\
280-0\end{array}$ \\
\hline \multirow[t]{2}{*}{ C } & $\begin{array}{l}17: 23-17: 45 \\
16: 25-17: 02\end{array}$ & & $\begin{array}{r}\cdot-0 \\
320-0\end{array}$ & $\begin{array}{l}23: 26-23: 45 \\
22: 20-23: 07\end{array}$ & & $\begin{array}{r}85-0 \\
310-0\end{array}$ \\
\hline & $\begin{array}{l}10: 56-11: 20 \\
11: 38-12: 29\end{array}$ & $2 \mathrm{Dec}$ & $\begin{array}{r}\cdot-0 \\
365-0\end{array}$ & $\begin{array}{l}10: 00-10: 32 \\
13: 49-14: 26\end{array}$ & $14 \operatorname{Jan}$ & $\begin{array}{l}115-0 \\
270-0\end{array}$ \\
\hline \multirow[t]{2}{*}{$\mathrm{D}$} & $\begin{array}{l}18: 32-18: 59 \\
19: 17-20: 02\end{array}$ & $3 \mathrm{Dec}$ & $\begin{array}{l}120-0 \\
135-0\end{array}$ & $\begin{array}{l}18: 52-19: 24 \\
18: 10-18: 36\end{array}$ & & $\begin{array}{r}75-0 \\
120-0\end{array}$ \\
\hline & $\begin{array}{l}12: 47-13: 04 \\
12: 08-12: 32\end{array}$ & $4 \mathrm{Dec}$ & $\begin{array}{r}90-0 \\
120-0\end{array}$ & $\begin{array}{l}15: 05-15: 28 \\
15: 46-16: 07\end{array}$ & & $\begin{array}{r}75-0 \\
130-0\end{array}$ \\
\hline
\end{tabular}

vals. Nevertheless, this treatment of the data proved to be useful for revealing differences in distribution between stations for some of the species.

To estimate the total number of individuals and the total biomass in the fjord, each station represented a stratum of the fjord. Based on the topography, we defined Str A. Stns B + C, and Stn D to represent strata as marked in Fig. 1. The inner northern branch (which could not be sampled) has been excluded from the estimates. The volumes of the strata were determined by planimetry. Total numerical and biomass estimates based on the night catches in the L-IKMT were obtained according to:

$$
B=\sum_{j=1}^{3} Y_{i} V_{l}
$$

where $B=$ biomass or individuals in the fjord; $Y_{1}=$ mean concentration in stratum $i_{i} V_{i}=$ volume of stratum $i$.

Confidence intervals were obtained according to Cochran (1977, p. 95-96) using Satterthwaite's approximation formula for calculating the effective number of degrees of freedom.

The relative sampling efficiencies of the 2 IKMT's varied between species. The relative sampling efficiencies of the L-IKMT was estimated for each species or group for biomass determination and given as:

$$
E_{\mathrm{L}}=C_{\mathrm{L}} / A_{\mathrm{L}}: C_{\mathrm{S}} / A_{\mathrm{S}}
$$

where $E_{\mathrm{L}}=$ relative efficiency of the L-IKMT; $C_{\mathrm{L}}=$ catch in the L-IKMT (per standardized tow length);
$A_{\mathcal{L}}=$ opening area of the L-IKMT; $C_{\mathrm{S}}=$ catch in the SIKMT (per standardized tow length); $A_{S}=$ opening area of the S-IKMT.

By comparing values for the 2 nets, the numerical and biomass estimates were adjusted in accordance with the most efficient gear (all results in Figs. 3 to 5 are adjusted). The total data set was treated in a single analysis of the vertical distributions. In this analysis, the results from Stns B and C (which were the stations where day-samples were obtained) were lumped together after calibration between the 2 nets. Thus, in Fig. 4, each histogram represents the mean depth intervals and the mean catches of 4 tows.

Temperature and salinity data were obtained by a Neil Brown CTD.

\section{RESULTS}

\section{January 1986}

Hydrography

CTD-profiles from the 4 stations are given in Fig. 2. The influence of the sill is clearly demonstrated. Below sill depth, temperature and salinity were identical throughout the fjord. Above sill depth, spatial variations in vertical profiles were less than temporal variations, as shown by the higher degree of resemblance in temperature and salinity profiles between Stns A and C on the same date than between the neighbouring Stns $B$ and $C$ on different dates (Fig. 2). The temporal 


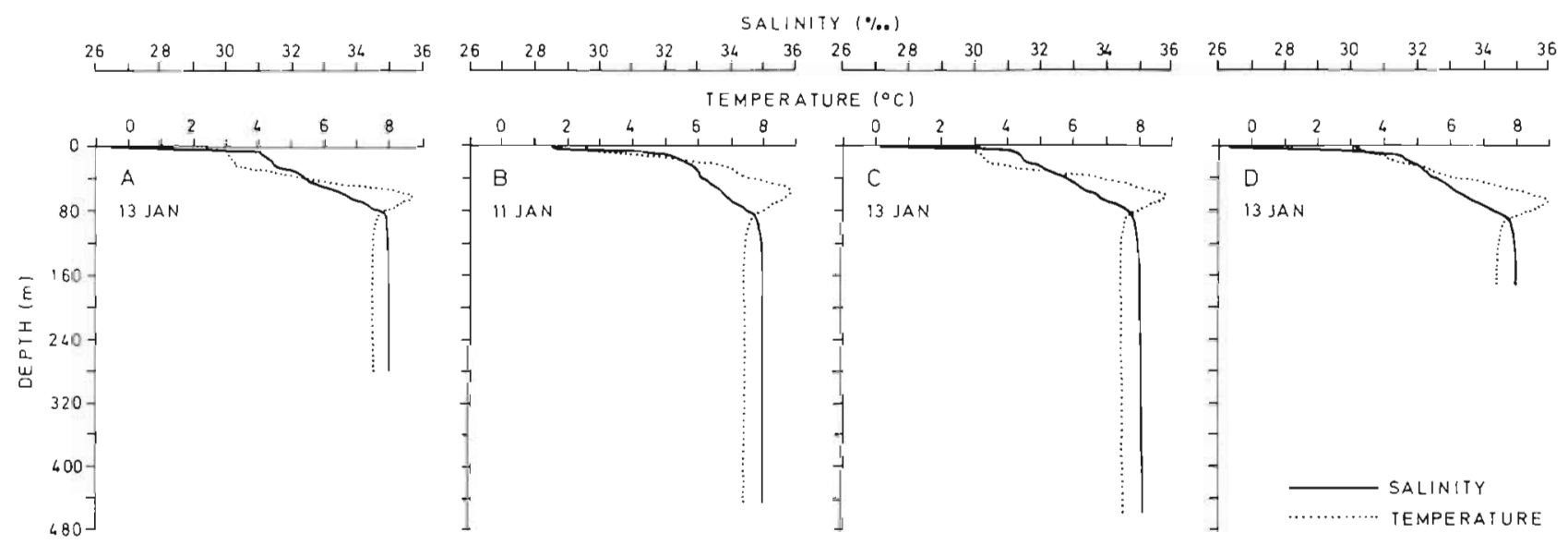

Fig. 2. Vertical temperature and salinity profiles at Stns A to D

variations indicate the dynamic nature of the water masses above sill depth.

Total numbers of common species

The mesopelagic fishes Benthosema glaciale (Reinhardt) and Maurolicus muelleri (Gmelin), the pelagic shrimps Pasiphaea multidentata Esmark and Sergestes arcticus Krøyer, and the euphausiid Meganyctiphanes norvegica (M. Sars) were the dominant macroplankton and micronekton in January 1986. Estimates of the total number of specimens in the fjord together with the relative sampling efficiencies of the L-IKMT (in terms of Eq. [2]) are given in Table 3. The 2 IKMT's seemed to be about equally efficient in catching $M$. muelleri. For all other species, the S-IKMT was the more efficient gear. The adjusted estimates indicate

Table 3. Estimates of the total number of individuals of 5 species in Masfjorden, January 1986. Relative sampling efficiencies of the L-IKMT are given. Adjusted estimates take into account the lower sampling efficiency of the L-IKMT compared to the S-IKMT

\begin{tabular}{|lrccc|}
\hline Species & $\begin{array}{c}\text { Total } \\
\text { number } \\
\left(\times 10^{6}\right)\end{array}$ & $\begin{array}{c}95 \% \\
\text { conf. int. }\end{array}$ & $\begin{array}{c}\% \\
\text { efficiency } \\
\text { L-IKMT }\end{array}$ & $\begin{array}{c}\text { Adjusted } \\
\text { estimate }\end{array}$ \\
\hline $\begin{array}{c}\text { Benthosema } \\
\text { glaciale }\end{array}$ & 5.2 & 2.1 & 41.3 & 12.5 \\
$\begin{array}{c}\text { Maurolicus } \\
\text { muelleri }\end{array}$ & 7.5 & 4.1 & 95.4 & 7.9 \\
$\begin{array}{c}\text { Pasipahea } \\
\text { multidentata }\end{array}$ & 1.4 & 1.1 & 17.6 & 7.8 \\
$\begin{array}{c}\text { Sergestes } \\
\text { arcticus }\end{array}$ & 4.5 & 2.5 & 56.0 & 8.0 \\
$\begin{array}{c}\text { Meganyctipha- } \\
\text { nes norvegica }\end{array}$ & 127.9 & 52.7 & 23.5 & 544.5 \\
\hline
\end{tabular}

that fishes and shrimps were present in approximately equal numbers in the fjord.

\section{Distribution of species}

Fish. Horizontal distribution. The distribution of Benthosema glaciale differed significantly between stations $(p<0.005)$, and this species was almost exclusively restricted to the deep mid-part of the fjord (Stns $B$ and $C_{i}$ Fig. 3). The catches at $S \operatorname{Cn} C$ were recurrently higher than at Stn B. Maurolicus muelleri was found all

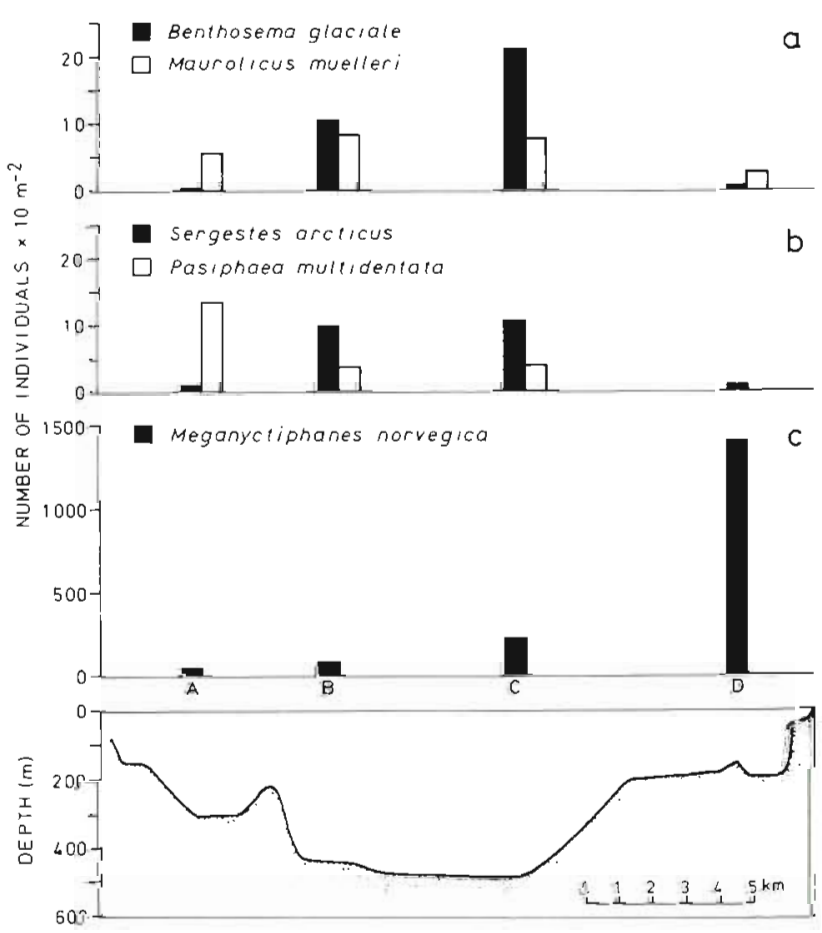

Fig. 3. Distribution of species of (a) fish, (b) shrimps, and (c) euphausiids along the fjord axis (Stns A to D) in January 1986 
along the fjord axis (Fig. 3), and no significant differences in number between stations were revealed.

Vertical distribution. Benthosema glaciale was mainly caught deeper than $200 \mathrm{~m}$ at day, while it was caught through the entire water column at night (Fig. 4). The largest catches of Maurolicus muelleri were obtained in the upper depth interval at night, and the catches decreased with increasing depth. A downward migration at day is indicated, but only low numbers of $M$. muelleri were found in the day samples (Fig. 4)

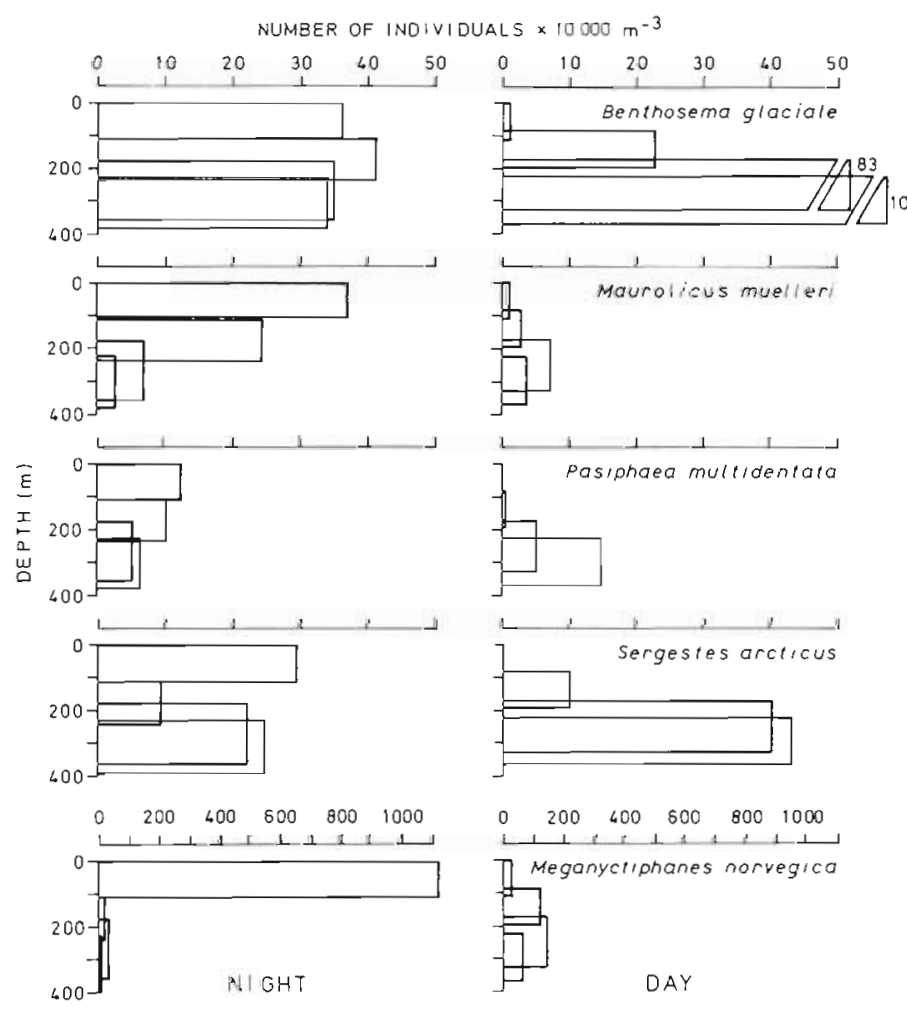

Fig. 4. Vertical distribution of fishes, shrimps, and euphausids at Stns B and C at night and day in January 1986. Bottom depth is ca $450 \mathrm{~m}$

Shrimps. Horizontal distribution. Catches differed significantiy between stations for both Pasiphaea multidentata $(p<0.001)$ and Sergestes arcticus $(p<0.005)$. $P$. multidentata was found in highest number at the outermost station (Stn $A$ ), but also regularly at Stns B and C (Fig. 3). The species was not caught at the inner Stn D. S. arcticus was mainly confined to the mid-part of the fjord (Stns B and C) with additional small catches at Stns $A$ and $D$. The 2 pelagic shrimps thereby had different domains of the fjord in which they were the prominent species.

Vertical distribution. During daylight, the shrimps generally left the upper 100 to $200 \mathrm{~m}$, and abundance increased with increasing depth. Catches at night included relatively high numbers of both Pasiphaea multidentata and Sergestes arcticus in the upper $100 \mathrm{~m}$ (Fig. 4).

Euphausiids. Horizontal distribution. There was an increase in catches of Meganyctiphanes norvegica from the outer fjord area towards the head of the fjord where a marked maximum was found (Fig. 3). Since $M$. norvegica was mainly confined to the upper depth strata at night (see below), there were marked differences between tows within a station, and the 'replicates' of the ANOVA differed accordingly (see 'Material and Methods'). The differences between the stations were therefore not significant $(p>0.05)$ with the present methods. Nevertheless, as the inward increase was even more pronounced in the series with the S-IKMT than in the results presented from the LIKMT, the observed differences between the stations obviously reflect real patterns.

Vertical distribution. Meganyctiphanes norvegica was confined to the upper $100 \mathrm{~m}$ at night, while there was an apparent maximum at mid-depth during the day (Fig. 4). The day samples contained, however, few specimens compared to the night samples.

\section{Total biomass in the fjord}

Estimates of the total biomass in the fjord of each group and all groups combined are given in Table 4. Adjusted estimates based on sampling efficiencies in

Table 4. Estimates of the total biomass (tonne AFDW) in Masfjorden, January 1986. The relative sampling efficiencies of the L-IKMT are given. Adjusted estimates take into account the lower sampling efficiency of the L-IKMT compared to the S-IKMT

\begin{tabular}{|lcccc|}
\hline Taxon & $\begin{array}{c}\text { Total } \\
\text { biomass }\end{array}$ & $\begin{array}{c}95 \% \\
\text { conf. int. }\end{array}$ & $\begin{array}{c}\% \\
\text { efficiency } \\
\text { L-IKMT }\end{array}$ & $\begin{array}{c}\text { Adjusted } \\
\text { estimate }\end{array}$ \\
\hline Fish & 3.8 & 1.4 & 55.7 & 6.8 \\
Shrimps & 1.2 & 0.5 & 30.6 & 4.0 \\
Euphausids & 2.2 & 1.5 & 25.6 & 8.6 \\
Other taxa & 0.4 & 0.3 & 17.4 & 2.2 \\
Total & 7.4 & 2.7 & 38.0 & 19.5 \\
\hline
\end{tabular}

composite samples differ from estimates based on mean sampling efficiencies for each group. Therefore, the total biomass presented differs somewhat from the sum of the biomasses of the groups. The biomass of fishes, pelagic shrimps and euphausiids were of the same order of magnitude. These groups constituted the bulk of the biomass of macroplankton and micronekton in the fjord during January 1986, as the biomass of the other taxa was relatively small. 
Distribution of biomass

Fishes. The biomass of fishes differed significantly between stations $(p<0.001)$. The biomass maximum in the deep mid-fjord basin (Fig. 5) was mainly contri-

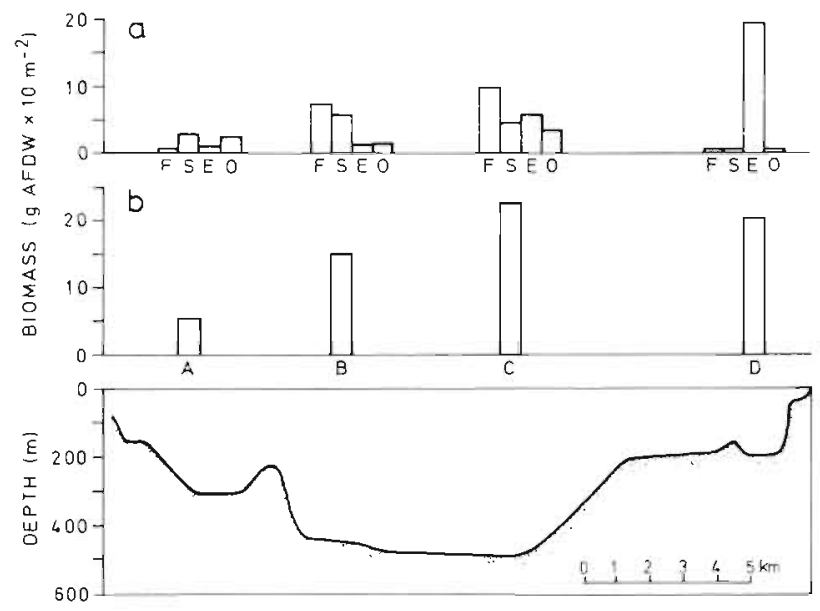

Fig. 5. (a) Distribution of biomass of fishes (F), shrimps (S), euphausiids (E), and combination of other taxa (O); (b) total biomass along the fjord axis (Stns A to D) in January 1986

buted by Benthosema glaciale. The size-distribution of Maurolicus muelleri had an additional impact to the mid-fjord biomass maximum, as the largest individuals of this species was found at $\operatorname{Stn} B$. The mean lengths of $M$. muelleri (with $5 \%$ confidence intervals) at Stns $A$, $\mathrm{B}, \mathrm{C}$, and $\mathrm{D}$ respectively were $2.4 \pm 0.3,4.1 \pm 0.1$, $2.9 \pm 0.2$, and $2.9 \pm 0.3 \mathrm{~cm}$

Shrimps. The biomass of shrimps differed significantly between stations $(p<0.005)$. The mid-fjord maximum in biomass (Fig. 5) was caused both by the abundance and by the size-distribution of the shrimps. Generally, the largest specimens were found in this deep basin. The mean carapax lengths of Pasiphaea multidentata (with $5 \%$ confidence intervals) at Stns $A$, $\mathrm{B}$, and $\mathrm{C}$ respectively were $7.0 \pm 0.3,10.4 \pm 4.2$, and $12.0 \pm 2.0 \mathrm{~mm}$. The mean carapax lengths in Sergestes arcticus at Stns B, C, and D respectively (only one individual measured at Stn A) were $7.4 \pm 0.5,6.9 \pm$ 0.4 , and $5.2 \pm 0.2 \mathrm{~mm}$.

Euphausiids. The biomass of euphausiids increased inwards with a marked maximum at the head of the fjord (Fig. 5). The differences between the stations were not significant $(p>0.05)$, but as mentioned earlier, this is mainly due to the high within-station variance caused by the vertical distribution of the euphausiids.

Other taxa. There were no significant differences in the biomass of the rest-group between the stations. The distribution is given in Fig. 5.
Biomass distribution of all groups combined. The biomass of all groups combined differed significantly between stations $(p<0.001)$. Stn A had the lowest mean biomass. Although fishes and shrimps were caught in low numbers at $\operatorname{Stn} D$, this was counteracted by the higher biomass of euphausiids.

\section{December 1986 and January 1987}

The biomass from the night sampling by the S-IKMT in December 1986 and January 1987 is given in Fig. 6. The sampling procedures differed from those of the

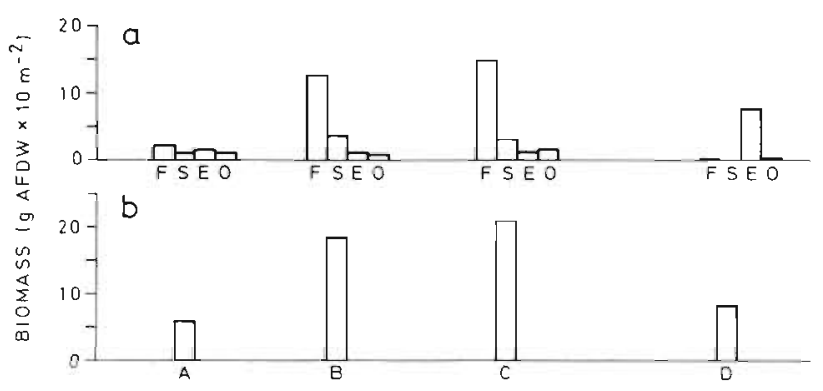

Fig. 6. (a) Distribution of mean biomass of fishes (F), shrimps (S), euphausiids (E), and combination of other taxa (O); (b) mean total biomass along the fjord axis (Stns $A$ to $D$ ) from the sampling in December 1986 and January 1987

preceding winter, and the results from winter 1986/ 1987 are means of 2 single tows at each station, separated by $1 \mathrm{mo}$. Interpretations must therefore be restricted to the main patterns. Nevertheless, comparing with the results in Fig. 5, the following conclusions seem justified: (1) the total biomass was within the same order of magnitude in both winters; (2) the distribution of biomass followed the same general pattern in both winters.

There are, however, 2 apparent discrepancies between the 2 data sets. Euphausiids Meganyctiphanes norvegica seemed to be more evenly distributed between the 3 outer stations during winter 1986/1987 (no increase inwards). This was also apparent from the night sampling in the upper depth interval both in December and January (results not shown). Nevertheless, Stn D still had the highest concentration of euphausiids. The abundance of euphausiids seemed to be somewhat lower than the preceding winter, leading to a lower total biomass at Stn D. Fishes seemed to be more prominent compared to shrimps in the catches from winter $1986 / 1987$, but the species composition and the general horizontal distributions of species corresponded with those found the previous winter. Benthosema glaciale was, as in January 1986, almost exclusively found at Stns B and C. Pasiphaea multiden- 
tata was the only pelagic shrimp found at Stn $A$, both shrimps were found at Stns B and C, and only one small specimen of Sergestes arcticus was caught at Stn D.

\section{DISCUSSION}

The results presented have revealed species-specific differences in sampling efficiencies by the 2 IKMT's. Generally, the S-IKMT had the highest catch/moutharea ratio. This was surprising, as we initially believed that the larger gear would be more efficient in sampling larger species. The lower efficiencies of the L-IKMT may be due to losses through the wide meshes in the front part of the net, or to unknown aspects of the gear performance. Sampling efficiency was comparable between the 2 nets only for Maurolicus muelleri. Netavoidance behaviour in this species is indicated by the low daytime catches compared to the night catches (cf. Fig. 4). Avoidance is also a possible explanation for the low day-time catches of Meganyctiphanes norvegica.

During day, the populations were to a large extent confined to the basin water (below sill depth). Oxygen deficiencies are not encountered in the main basins of Masfjorden. During a 4 yr study, the oxygen level in the deep water ranged between 3.7 and $5.5 \mathrm{ml} \mathrm{O}_{2} \mathrm{l}^{-1}$. In this period, one total and one partial renewal of the basin water was indicated ( $\mathrm{J}$. Aure, Institute of Marine Research, Bergen, pers. comm.). The basin water offers a very homogenous environment with respect to temperature and salinity (Fig. 2). In our study, from ca $100 \mathrm{~m}$ downwards, temperature ranged between 7.40 and $7.45^{\circ} \mathrm{C}$ and salinity ranged between 34.92 and $34.99 \%$. Above sill depth, on the other hand, there are marked gradients in the hydrographic parameters (Fig. 2). Thus, organisms which during vertical migrations at night ascend into this layer encounter abrupt changes in their physical environment. Clearly, all species were represented in the upper $100 \mathrm{~m}$ at night (Fig. 4), and there was no apparent effect on the migrations from these gradients. However, the present vertical resolution of the sampling does not permit a detailed discussion of this question.

As the temperature and salinity profiles were more or less identical throughout the fjord, hydrographic conditions may not explain the horizontal distributional patterns of macroplankton and micronekton in Masfjorden. The topography of the fjord, currents, and biological interactions are the most probable factors governing the distributions along the fjord axis.

Deep-living species may require depths suitable for daytime residence to maintain viable populations. The topography of the fjord, therefore, probably plays a key-role in determining the distribution of some of the species. A bathymetric effect is apparent in the dis- tribution of Benthosema glaciale, which was almost exclusively found at the deep Stns B and C. The bottom depths of these locations correspond to what has earlier been found to be the depth of main daytime distribution of adult $B$. glaciale in northern Atlantic populations (Halliday 1970, Roe \& Badcock 1984). The vertical daytime distribution found during our sampling in Masfjorden, however, does not explain the almost total absence of this species from Stn A (Fig. 3).

Maurolicus muelleri had a more widespread distribution than Benthosema glaciale, but the larger individuals of $M$. muelleri seemed to accumulate at Stn B. Lopes (1979) found this region of the fjord to be the main spawning area of $M$. muelleri. The maximum abundance of large individuals was in the other part of the deep basin than the numerical maximum of $B$. glaciale. This partial partitioning of the habitat may tentatively be related to interactions between the 2 species of mesopelagic fish. Euphausids have been found to be the prominent food for $M$. muelleri in Norwegian fjords during winter (Gjøsæter 1981), which, if true in Masfjorden, would imply a preference in January 1986 for the innermost stations. For $B$. glaciale, both euphausiids and copepods seem to be important winter-food (Gjøsæeter 1973). Roe \& Badcock (1984) state that no doubt different distributions, migrations and feeding behaviour all interact to reduce competition between species [of mesopelagic fish].

The distribution of the shrimps in Masfjorden, like the fishes, may partly be governed by the topography of the fjord, and partly by biological interactions. The biomass maxima of shrimps at the deep Stns B and C are in accordance with published results on their vertical distribution. Matthews \& Pinnoi (1973) found that most specimens of Pasiphaea multidentata occurred between 300 and $400 \mathrm{~m}$ during the day in Korsfjorden, western Norway. They also found that the larger individuals of this species tended to occur deeper than the smaller ones. Roe (1984) reported a shift towards deeper distribution of Sergestes arcticus with increasing size. Neither existing information on the vertical distributions of $P$. multidentata and $S$. arcticus (Matthews \& Pinnoi 1973, Omori 1974, Fasham \& Foxton 1979, Hargreaves 1984, Roe 1984) nor our findings from Masfjorden (Fig. 4) give any indications of different daytime depth preferences between the species. It may be that the horizontal separation ( $P$. multidentata being numerically dominant at $S \operatorname{Stn} \mathrm{A}_{\text {, }}$ and $S$. arcticus numerically dominant at $B$ and $C$ ), arise from biological interactions. Roe (1984) studying the vertical distribution of assemblages of decapods, found spatial separation of species which he asserts could provide a means of avoiding competition.

The euphausiid distribution seemed to be unrelated to the fjord topography. We hypothesize that the 
marked maximum at the head of the fjord is due to accumulation by physical advection. In accordance with our findings on the euphausiids, marked maxima of other planktonic organisms (Calanus finmarchicus) have at times been found at the head of Masfjorden (Anonymous 1980) and in other fjords of western Norway (Fosshagen 1980). Anonymous (1980) ascribes the accumulation to estuarine circulation, while according to Fosshagen (1980), such events were most prominent following periods of strong and steady outfjord winds. The outgoing water transport in upper layers set up an ingoing countercurrent, transporting water rich in plankton to the head of the fjord. Prevailing southerly winds along the coast may likewise be of importance, as they cause an inward water transport in the upper part of the intermediate layer of western Norwegian fjords (Svendsen 1981). Evidence for the importance of current transport of mesoplankton in Masfjorden will appear in a future paper (Aksnes et al. unpubl.).

In the present study, it is noteworthy that only the euphausiids seemed to be significantly advected. The decapods, on the other hand, were retained in specific parts of the fjord and were apparently as able as the nektonic fishes in sustaining their populations without appreciable displacement. Some dispersion may take place, e.g. the scattered records of small specimens of Sergestes arcticus at the relatively shallow inner Stn D, but juvenile decapods also were most abundant in restricted areas. Although the decapods may be good swimmers, the present and related species have, at least in more exposed areas, been considered as truly planktonic (Pereyra et al. 1969, Matthews \& Bakke 1977). Transport of the euphausiids may be enhanced by their generally shallower vertical distribution at night, and the presence of a sill will favour retention in deeper-living species. The basin water of fjords may actually represent a potential refuge for pelagic organisms endemic to the fjord. However, a number of factors would also favour physical advection in the shrimps. The water masses may flow freely between the different parts of the fjord in the upper $150 \mathrm{~m}$ where there are no physical obstacles to horizontal water transport. The shrimps were well represented in the upper $100 \mathrm{~m}$ in the night catches, and winter nights at these latitudes last for up to $18 \mathrm{~h}$. In more recent investigations in Masfjorden, we have sampled with higher vertical resolution above sill depth (using MOCNESS) and at the same time obtained current profiles by an Acoustic Doppler Current Profiler (ADCP) which registers currents from a moving vessel. In this sampling, we have found both species of shrimps in currents of up to approximately $15 \mathrm{~cm} \mathrm{~s}^{-1}$ during their vertical migrations at night (unpubl.). Still, the horizontal distribution in Masfjorden is 'chosen' by the shrimps themselves according to locations offering suitable daytime habitats. It appears that while animals which are seemingly without specific daytime habitat requirements in Masfjorden (i.e. the euphausiids and copepods) are vulnerable to transport by currents, species having reasons for maintaining specific positions in the fjord are able to do so. A thorough discussion of the role of retention in population maintainance of pelagic organisms is given by Sinclair (1988).

\section{Macroplankton and micronekton as food for cod}

None of the groups studied (Table 4) seem to be important food items for the cod stock which at present inhabits Masfjorden (Salvanes 1986). However, these groups may represent a potential food source if the cod change their feeding habits when the stock becomes artificially increased. The 0-group cod stock in 1986 has been estimated to consist of 10000 to 20000 individuals (A. G. Salvanes, Institute of Marine Research, Bergen, pers. comm.), while the planned autumn release may include several hundred thousand codlings. In Loch Torridon, western Scotland, Hawkins et al. (1985) estimated an average food intake of approximately $2 \mathrm{~g}$ wet weight $\mathrm{d}^{-1}$ for 0 -group cod in the period December to February, while the daily food-intake in the same time-span during the second year of life would be ca $7.2 \mathrm{~g}$. Growth in this period was inhibited by shortage of food. Juvenile coastal cod in western Norway are approximately the same size, or slightly larger than, juvenile cod in the Scottish loch (Hawkins et al. 1985, Svåsand \& Kristiansen 1985). Our sampling gives an estimated winter standing stock of macroplankton and micronekton of $19.5 \mathrm{t}$ AFDW (tonne ashfree dry weight) (Table 4). Using the food intake estimate of Hawkins et al. (1985) (which has proved to limit growth) and adapting these to the vertical temperature range found in Masfjorden (a minimum of $2.5^{\circ} \mathrm{C}$ at the surface to a maximum of $8.8^{\circ} \mathrm{C}$ at ca $60 \mathrm{~m}$ ), it appears that in their first year of life $500000 \mathrm{cod}$ would require 14.8 to $18.5 \mathrm{t}$ AFDW of food (based on a conversion factor AFDW: WW of $1: 5$ ) during the period December to February. For cod during their second year of life, this estimate corresponds to the food requirements of 140000 individuals. Such numbers of juvenile cod would therefore during a winter period have food requirements almost corresponding to the entire estimated winter standing stock of macroplankton and micronekton in Masfjorden.

Data is not available to evaluate the production potential of the macroplankton and micronekton nor to evaluate the fraction available as food for cod. However, for a rough assessment to give the order of magnitude of the contribution from these groups such information may not be necessary. Lack of information on 
advective rates in the euphausiids, which is the only group dealt with that seems vulnerable to advection, may be more serious. From values on residual currents in Masfjorden given by Aksnes et al. (unpubl.), the residence times of the water above sill depth during cruises in June and October 1985 were estimated at ca $12 \mathrm{~d}$ and $5 \mathrm{wk}$ respectively. For the relatively longliving euphausiids (Meganyctiphanes norvegica may reach an age of 2 yr in western Norwegian fjords; Matthews 1973), this indicates that advection may be much more important for the standing stock in the fjord than the internal biological production. A more comprehensive discussion of the relationship between local production and advection as it bears on the carrying capacity of a fjord system will appear in Aksnes et al. (unpubl.). With the reservations of these lacking data, we conclude that although our estimates indicate some pelagic 'food reserve', the macroplankton and micronekton in Masfjorden does not seem to provide a food resource on which several hundred thousand codlings may rely during winter. To evaluate the actual increase in the cod population which may be sustained by these groups, data are needed on production, advective rates, and the fractions of the populations which are available to the cod.

Acknowledgements. We thank $\mathrm{T}$ Brattegard and U. Lie for helpful criticisms of the manuscript. T Brattegard and J. H. Fosså gave valuable help during the field work. Figures were drawn by Elin Holm. We are grateful to the captain and crew of RV 'Hakon Mosby' for their cooperation and assistance.

\section{LITERATURE CITED}

Anonymous (1980). Havmiljøet og havundersøkelser i de norske fiskeriområder i 1978. Fisk. Hav 1980 (Sarnr. 1). (Norwegian)

Anonymous (1981). Manual for the international young fish surveys in the North Sea, Skagerrak and Kattegat. Coun. Meet. int. Coun. Explor. Sea C.M.-ICES/H: 9

Aron. W. (1962). Some aspects of sampling the macroplankton. Rapp. P.-v. Réun. Cons. perm. int. Explor. Mer 153: $29-38$

Cochran, W G. (1977). Sampling techniques. John Wiley \& Sons, Inc, New York

Daan, N. (1973). A quantitative analysis of the food intake of North Sea cod, Gadus morhua. Neth. J. Sea Res. 6: $479-517$

Falk-Petersen, S. Hopkuns, C. C. E. (1981). Zooplankton sound scattering layer in North Norwegian fjords: interaction between fish and krill shoais in winter in Ullsfjorden and Øksfjorden. Kieler Meeresforsch. Sonderheft 5: $191-201$

Fasham, M. J. R. Foxton, P. (1979). Zonal distribution of pelagic Decapoda (Crustacea) in the eastern north Atlantic and its relation to the physical oceanography. J. exp. mar Biol. Ecol. 37: 225-253

Fosshagen, A. (1980). How the zooplankton community may vary within a single fjord system. In: Freeland, J., Farmer,
D. M., Levings, C. D. (eds.) Fjord oceanography. Plenum Publishing Corp., New York, p. 399-405

Gjøsæter, J. (1973). The food of the myctophid fish Benthosema glaciale (Reinhardt), from western Norway. Sarsia 52: $53-58$

Gjøsæter, J. (1981). Life history and ecology of Maurolicus muelleri (Gonostomatidae) in Norwegian waters. FiskDir. Skr. Ser. Havunders. 17: 109-131

Halliday, R. G. (1970). Growth and vertical distribution of the glacier lanternfish, Benthosema glaciale, in the northwestern Atlantic. J. Fish. Res. Bd Can. 27 105-116

Hargreaves, P. M. (1984). The distribution of Decapoda (Crustacea) in the open ocean and near-bottom over an adjacent slope in the northern north-east Atlantic ocean during autumn 1979. J. mar, biol. Ass. U.K. 64: 829-857

Hawkins, A. D., Soofiani, N. M., Smith, G. W. (1985). Growth and feeding of juvenile cod (Gadus morhua L.). J. Cons. int. Explor. Mer 42: 11-32

Klemetsen, A. (1982). Food and feeding habits of cod from Balsfjorden, northern Norway during a one-year period. J. Cons. int. Explor. Mer 40: 101-111

Lopes, P. D. C. (1979). Eggs and larvae of Maurolicus muelleri (Gonostomatidae) and other fish eggs and larvae from two fjords in western Norway. Sarsia 64: 199-210

Matthews, J. B. L. (1973). Ecological studies on the deep-water pelagic community of Korsfjorden, western Norway. Population dynamics of Meganyctiphanes norvegica (Crustacea, Euphausiacea) in 1968 and 1969. Sarsia 54: 75-90

Matthews, J. B. L., Bakke, J. L. W. (1977). Ecological studies on the deep-water pelagic community of Korsfjorden (western Norway). The search for a trophic pattern. Helgoländer wiss. Meeresunters. 30: 47-61

Matthews, J. B. L., Pinnoi, S. (1973). Ecological studies on the deep-water pelagic community of Korsfjorden, western Norway. The species of Pasiphaea and Sergestes (Crustacea, Decapoda) recorded in 1968 and 1969. Sarsia 52: 123-144

Motoda, S. (1959). Devices of simple plankton apparatus. Mem. Fac. Fish. Hokkaido Univ, 7: 73-94

Omori, M. (1974). The biology of pelagic shrimps in the ocean. Adv. mar. Biol. 12: 233-324

Pereyra, W T., Pearcy, W G., Carvey, F. E. Jr. (1969). Sebastoides flavidus, a shelf rockfish feeding on mesopelagic fauna, with consideration of the ecological implications. J. Fish. Res. Bd Can. 26: 2211-2215

Rae, B. B. (1968). The food of cod in Icelandic waters. Mar Res. 1968 (6): 1-19

Roe, H. S. J. (1984). The diel migrations and distributions within a mesopelagic community in the north east Atlantic. Vertical migrations and feeding of mysids and decapod Crustacea. Prog. Oceanogr 13: 269-318

Roe, H. S. J., Badcock, J. (1984). The diel migrations and distributions within a mesopelagic community in the north east Atlantic. Vertical migrations and feeding in fish. Prog. Oceanogr. 13: 389-424

Sætre, R. (1974). En hydrografisk undersøkelse i Matrevågen, Nordhordland. Fisk. Hav. (Ser. B) 1974 (6). (Norwegian)

Salvanes, A. G. V (1986). Preliminary report from a comparative study of the diet of four gadoid fishes in a fjord of western Norway. Coun. Meet. int. Coun. Explor. Sea C.M.ICES/G: 71

Santos, J. dos, Falk-Petersen, S. (in press). Feeding ecology of cod (Gadus morhua L.) in Balsfjord and Ullsfjord, north Norway, 1982-83. J. Cons. int. Explor. Mer

Sinclair, M. (1988). Marine populations: an essay on population regulation and speciation. Washington Sea Grant, Seattle (in press) 
Sokal, R. R., Rohlf, F. J. (1981). Biometry. W. H. Freeman and Co., San Francisco

Svendsen, H. (1981). A study of circulation and exchange processes in the Ryfylkefjords. Ph.D. thesis, University of Bergen, Norway
Svåsand, T., Kristiansen, $T$ (1985). Release of artificially reared 0-group cod (Gadus morhua L.) in a landlocked fjord in western Norway. Coun. Meet. int. Coun. Explor. Sea C.M.-ICES/F: 10

This article was submitted to the editor; it was accepted for printing on April 7, 1988 